\title{
Atypical presentation of a giant spinal schwannoma
}

\author{
Wen-Shan Sung, ${ }^{1}$ Jeeuk Song, ${ }^{2}$ Arvind Dubey ${ }^{1}$ \\ ${ }^{1}$ Department of Neurosurgery, Royal Hobart Hospital, Hobart, Australia \\ ${ }^{2}$ Gold Coast Hospital, Southport, Australia
}

Correspondence to Jeeuk Song, jeeuk@hotmail.com

\section{DESCRIPTION}

Spinal schwannomas are peripheral nerve sheath tumours thataccount forapproximately $30 \%$ of extramedullaryspinal cord tumours, found predominantly in sensory roots of the spinal nerve and occasionally in motor roots. ${ }^{1}$ Most spinal schwannomas are small, well encapsulated and intradural. However, 10-15\% extend through the dural root sleeve as dumbbell tumours with both intradural and extradural components, and approximately $2-10 \%$ are entirely extradural. ${ }^{2}$

According to Seppälä et al, the incidence of spinal schwannomas varies between 0.3 and 0.4 cases per 100000 persons per year with no statistical difference in prevalence between males and females. ${ }^{3}$ Although their malignant potential is low, they can be locally destructive if allowed to progress.

We report an atypically large extradural spinal schwannoma, which was initially discovered on chest x-ray during work-up for flu-like symptoms and episodes of difficulty in breathing. Interestingly, our 76-year-old male patient was free of neurological symptoms and had an otherwise insignificant past medical history.

CT scans of the thorax showed this lesion to be paravertebral in location and associated with erosion of the posterior right ribs and a thoracic vertebral body. Subsequent MRI scans (figure 1) demonstrated that the tumour was approximately $6 \times 8 \times 8 \mathrm{~cm}$ in size (figure 2 ) and extended from the $T 5 / 6$ to $T 8 / 9$ disc with intraspinal extension through the intervertebral foramen at the T8/9 level. A core biopsy was obtained through CT guidance and the histological findings of the tissue revealed typical features of a benign schwannoma with both hypercellular Antoni type A and pauci-cellular Antoni type B tissue.

Like most other extramedullary neoplasms, spinal schwannomas usually produce local segmental deficits before distant neurological deficits appear. Cervical lesions can produce weakness, fasciculation and atrophy of hand muscles. Thoracic lesions can produce band paraesthesia or Horner's syndrome, while lumbosacral lesions can produce lower extremity weakness as well as bladder and bowel symptoms. ${ }^{4}$

After a careful preoperative evaluation, it was decided that surgery should be performed in a joint effort with the cardiothoracic team. Intraoperatively, the tumour was seen to be densely adherent to the spinal nerve roots, lung, oesophagus and ribs. It appeared that the tumour was extradural in origin and there was no evidence of intradural extension. The tumour was successfully removed from these structures.

In summary, spinal schwannomas may present as unrecognised slow growing tumours. Their deceptive benign classification should not lead to underestimation of their potential size and the damage they can do to surrounding structures. An accurate preoperative diagnosis is important so that proper management can be prepared.

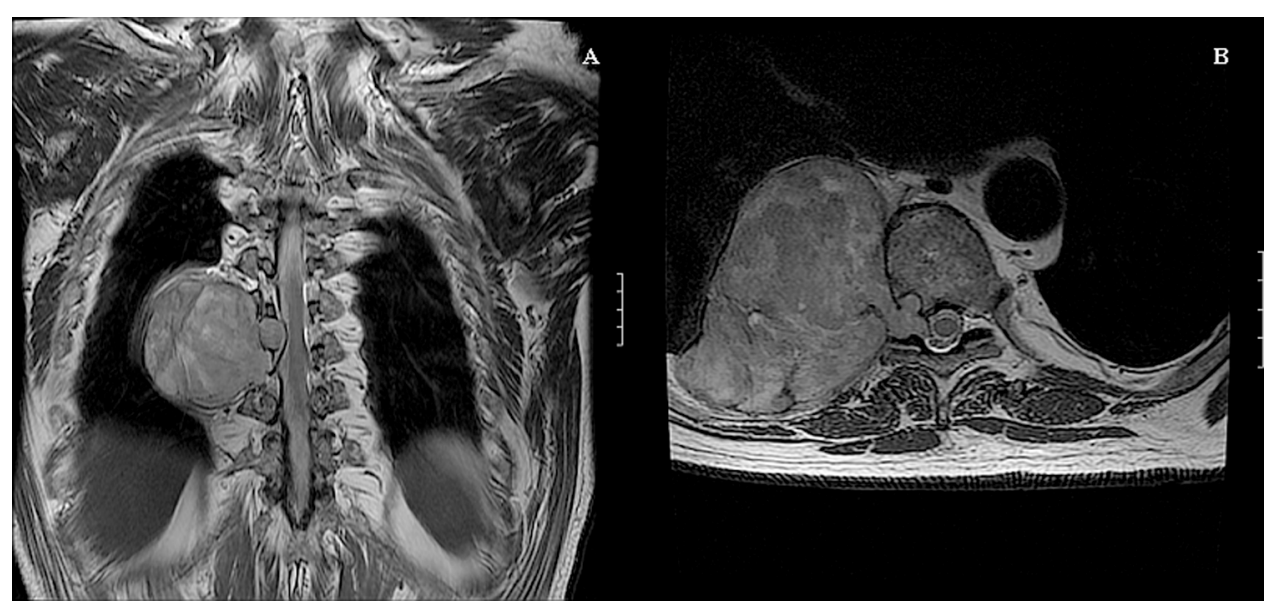

Figure 1 (A) T2-weighted coronal MRI showing the tumour extending from approximately the T5/6 disc to the T8/9 disc. (B) T2-weighted axial MRI showing infiltration of the tumour into the spinal canal. 


\section{BMJ Case Reports}

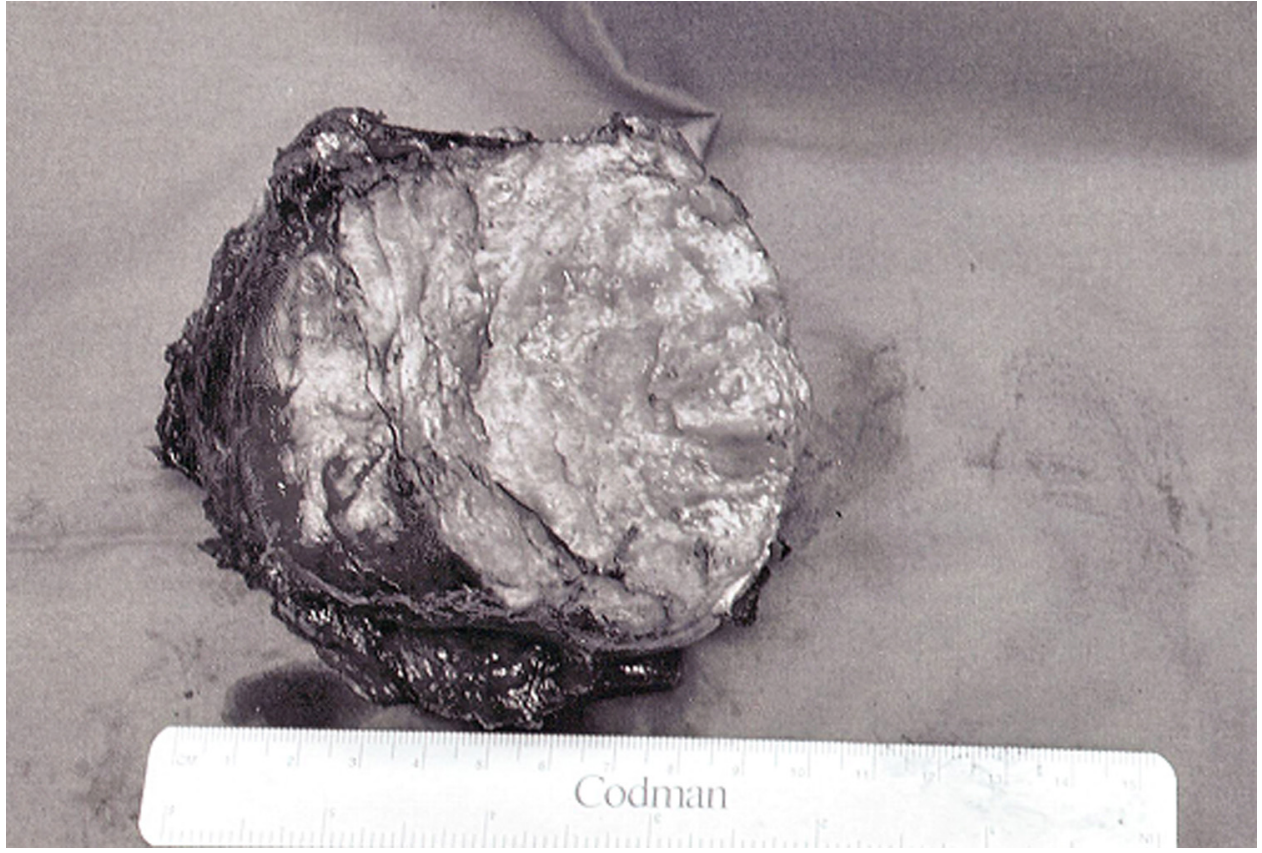

Figure 2 Tumour $6 \times 8 \times 8 \mathrm{~cm}$ in size.

Competing interests None.

Patient consent Obtained.

\section{REFERENCES}

1. Masaryk TJ. Neoplastic disease of the spine. Radiol Clin North Am 1991;29:829-45.

2. Bhatia S, Khosla A, Dhir R, et al. Giant lumbosacral nerve sheath tumors. Surg Neurol 1992;37:118-22.
3. Seppôlô MT, Haltia MJ, Sankila RJ, et al. Long-term outcome after removal of spinal schwannoma: a clinicopathological study of 187 cases. J Neurosurg 1995;83:621-6.

4. Miura J, Doita M, Miyata K, et al. Horner's syndrome caused by a thoracic dumbbell-shaped schwannoma: sympathetic chain reconstruction after a one-stage removal of the tumor. Spine 2003;28:E33-6.

This pdf has been created automatically from the final edited text and images.

Copyright 2010 BMJ Publishing Group. All rights reserved. For permission to reuse any of this content visit

http://group.bmi.com/group/rights-licensing/permissions.

BMJ Case Report Fellows may re-use this article for personal use and teaching without any further permission.

Please cite this article as follows (you will need to access the article online to obtain the date of publication).

Sung W-S, Song J, Dubey A. Atypical presentation of a giant spinal schwannoma. BMJ Case Reports 2010;10.1136/bcr.04.2010.2885, date of publication

Become a Fellow of BMJ Case Reports today and you can:

Submit as many cases as you like

- Enjoy fast sympathetic peer review and rapid publication of accepted articles

- Access all the published articles

Re-use any of the published material for personal use and teaching without further permission

For information on Institutional Fellowships contact consortiasales@bmjgroup.com

Visit casereports.bmj.com for more articles like this and to become a Fellow 